\title{
Frekuensi Pertemuan Dewan Komisaris dan Komite Audit Terhadap Manajemen Laba Dengan Pendekatan Non-Discreationary Accruals
}

\author{
Siti Wafiqoh Maulidiyyah Nurul Ichsany \\ STIE International Golden Institute \\ Email:vikamdi21@gmail.com \\ T.Husain \\ STMIK Widuri \\ Email:thusain1819@gmail.com
}

\begin{abstract}
This research aim to obtain empirical evidence about the practice of earnings management in use of corporate governance mechanism which consists of the frequency of board and audit committees meeting. This study uses measurements of earnings management with the non-discreationary accruals (NDA) approach introduced by Jones. The population of this study is sub-sectors companies in the construction and building in 2010-2016. The sampling technique uses a purposive method. The method of data analysis uses multiple regression analysis, the classical assumption test previously and followed by hypothesis testing. The results of this research indicate that the frequency of board meetings does not significantly influence on the earnings management, while the frequency of audit committee meetings has a negative effect on the earnings management.
\end{abstract}

Keywords: Earnings, management, frequency of audit committee meeting

\begin{abstract}
Abstrak
Penelitian ini bertujuan untuk membuktikan secara empiris mengenai adanya praktik manajemen laba dalam mekanisme corporate governance yang terdiri dari frekuensi pertemuan dewan komisaris dan komite audit. Penelitian ini menggunakan pengukuran manajemen laba dengan pendekatan non-discreationary accruals (NDA) yang diperkenalkan oleh Jones. Populasi penelitian ini adalah perusahaan pada sub sektor konstruksi dan bangunan tahun 2010-2016. Teknik sampling menggunakan metode purposive. Metode analisis data menggunakan analisis regresi berganda, dilakukan uji asumsi klasik terlebih dahulu serta dilanjutkan dengan uji hipotesis. Hasil penelitian ini menunjukkan bahwa frekuensi pertemuan dewan komisaris tidak berpengaruh signifikan terhadap manajemen laba, sementara frekuensi pertemuan komite audit berpengaruh negatif terhadap manajemen laba.
\end{abstract}

Kata kunci: Manajemen laba, frekuensi pertemuan komite audit

\section{Pendahuluan}

Standar Akuntansi Keuangan (SAK) memberikan kelonggaran kepada setiap perusahaan dalam memilih metode atau kebijakan akuntansi dalam penyusunan laporan keuangan. Kelonggaran dalam metode atau kebijakan ini dapat dimanfaatkan untuk menghasilkan nilai laba yang berbeda-beda di tiap-tiap perusahaan. Sebagai contoh, perusahaan yang memilih metode penyusutan straight-line akan memiliki perbedaan atas hasil laba usaha yang dilaporkan dengan perusahaan yang menggunakan metode angka tahun atau doubledeclining.Informasi yang terdapat dalam laporan laba rugi ini sering menjadi target rekayasa yang dilakukan manajemen perusahaan. Perilaku manajemen untuk mengatur laba sesuai keinginannya tersebut dikenal dengan istilah praktik manajemen laba (Yasa \& Novialy, 2012). 
Manajemen laba digunakan untuk mempengaruhi tingkat pendapatan laba untuk kepentingan manajemen maupun pemegang saham (stakeholders'). Manajemen laba secara praktis merupakan suatu aktivitas rekayasa manajerial yang cukup sulit untuk dideteksi karena meskipun laporan keuangan menyertakan catatan yang mengungkapkan secara rinci komponen-komponen dalam laporan keuangan,pemakai laporan keuangan tidak mempunyai kemampuan yang memadai untuk memahami catatan-catatan tersebut secara baik, dan tidak semua metode atau prosedur yang dipakai perusahaan dapat dipahami oleh pemakai laporan keuangan (Sulistyanto, 2014).

Perilaku dalam merekayasayang dilakukan oleh manajer yang berawal dari konflik kepentingan dapat dikurangi melalui suatu mekanisme monitoring yang bertujuan untuk menyelaraskan berbagai kepentingan tersebut. Fenomena yang terkait dengan manajemen laba terjadi beberapa tahun terakhir ini diantaranya: (1) Kasus PT Inovisi Infracom (kode saham - INVS) pada tahun 2015 atas indikasi salah saji dalam laporan keuangan periode September 2014 antara lain revisi nilai aset tetap, laba bersih per saham, laporan segmen usaha, kategori instrumen keuangan, dan jumlah kewajiban dalam informasi segmen usaha yang diminta oleh BEI. Praktik manajemen laba yang diterapkan berdampak pada laba bersih per saham tampak lebih besar(Bareska.com, 2015). (2) Kasus Toshiba Corp. yang melaporkan kerugian bersih sebesar 10 miliar yen (Rp1,17 triliun) pada laporan keuangan tahun 2014-2015. Teknik manajemen laba yang digunakan melalui melakukan mark-up atas keuntungan US\$12 miliar dolar selama beberapa tahun yang dibuktikan dari hasil penyelidikan yang dilakukan akuntan independen (Kompas.com, 2015). Kasuskasus terjadi dilatarbelakangi oleh pilihan pihak manajemen yang dirasa paling menguntungkan dengan memilih teknik manajemen laba tertentu yang diizinkan oleh Standar Akuntansi Keuangan (SAK). Semakin banyaknya aktifitas manajamen laba yang dilakukan perusahaan menjadi faktoryang mendorong berkembangannya perhatian publik terhadap konsep good corporate governance GCG).

Good corporate governance (GCG) diklasifikasikan menjadi struktur dan mekanisme GCG. Struktur GCG terdiri dari Rapat Umum Pemegang Saham, Dewan Direksi dan Dewan Komisaris, sedangkan mekanisme GCG merupakan aturan main, prosedur dan hubungan yang jelas antara pihak yang mengambil keputusan dengan pihak yang melakukan kontrol (pengawasan) terhadap keputusan tersebut.Keberadaancorporate governance memiliki implikasi luas dan kritikal terhadap perkembangan ekonomi dan kesejahteraan sosial. Untuk membangun sistem pengawasan dan pengendalian yang efektif dalam suatu perusahaan terdapat2 (dua) pihak yang diperlukan, yaitu komisaris independen (board of commisioner) dan komite audit (audit committee).

Berdasarkan peraturan yang dikeluarkan oleh Otoritas Jasa Keuangan Nomor 55/POJK.04/2015 tanggal 23 Desember 2015 tentang Pembentukan dan Pedoman Pelaksanaan Kerja Komite Audit, tujuan dibentuknya Komite Audit adalah untuk memastikan penerapan tata kelola perusahaan. Komite audit yang merupakan bagian organ dewan komisaris dan menjadi pihak yang memiliki akses langsung dan mekanisme komunikasi dengan berbagai pihak dalam setiap unsur pengendalian dalam perusahaan(Baskoro, 2017). Pihak komite audit dan dewan komisaris umumnya menyelenggarakan pertemuan minimal tiga sampai empat kali pada setiap tahunnya. 
Good corporate governance mulai menarik perhatian publik sebagai akibat publisitas masalah-masalah korporasi, seperti creative accounting, kebangkrutan perusahaan dalam skala yang sangat besar, penyalahgunaan dana stakeholders' oleh para manajer serta terbatasnya peran auditoryang menjadi akibat dari praktik-praktik manajemen laba yang diterapkan oleh perusahaan yang terkadang merugikan perekonomian secara keseluruhan (Sulistyanto, 2014).

Manajemen laba diklasifikasikan menjadi 2 (dua) kategori yaitu manajamen laba akrual dan manajemen laba nyata. Pendekatan model Jones tahun 1991 dan model Jones yang Dimodifikasi tahun 1995 merupakan spesifikasi dari model manajemen laba berada pada sifat estimasi diskresi akrual (discretionary accrual).Model Jones merupakan model yang dipandang memiliki kekuatan dalam mendeteksi kenaikan laba yang disebabkan manipulasi akrual dalam mendeteksi praktek manajemen laba (Algharaballi \& Albuloushi, 2008; Husain \& Surachman, 2017).

Penelitian tentang manajemen laba telah banyak dilakukan dengan objek pada perusahaan-perusahaan yang terdaftar di Bursa Efek Indonesia (BEI) mencakup sektor utama, sektor manufaktur dan sektor jasa. Beberapa hasil penelitian terdahulu yang menguji pengaruh mekanisme GCG yang berfokus pada frekuensi pertemuan atau rapat dewan komisaris dan komite audit dalam mendeteksi manajemen laba antara lain: (1) Pengaruh Karakteristik Dewan Komisaris dan Komite Audit terhadap Manajemen Laba pada perusahaan anufaktur yang terdaftar di BEI tahun 2009-2011. Metode analisis menggunakan analisis regresi berganda dengan bantuan program SPSSdimana hasil penelitian menunjukkan bahwa bahwa frekuensi pertemnuan dewan komisaris dan komite audit tidak berpengaruh signifikan terhadap manajemen laba (Prastiti \& Meiranto, 2013); dan (2) Pengaruh Ukuran Komite Audit, Audit Eksternal, Jumlah Rapat Komite Audit, Jumlah Rapat Dewan Komisaris dan Kepemilikan Intitusinal terhadap Manajemen Laba pada perusahaan manufaktur yang terdaftar di BEI tahun 2012-2014. Metode analisis menggunakan analisis regresi berganda dengan bantuan program SPSS, dimana hasil penelitian menunjukkan bahwa bahwa rapat dewan komisaris tidak berpengaruh signifikan terhadap manajemen laba sementara rapat komite audit berpengaruh negatif terhadap manajemen laba (Marsha \& Ghozali, 2017).

Pemilihan objek penelitian pada sub sektor konstruksi dan bangunan dilatarbelakangi oleh Masterplan Percepatan dan Perluasan Pembangunan Ekonomi Indonesia (MP3EI) dalam jangka panjang serta Fasilitas Persiapan Proyek Asia-Pasifik (AP3F) di tahun 2015 yang memprioritaskan proyek infrastruktur kemitraan publik-swasta dengan kerjasama regional, pembangunan berkelanjutan dan elemen perubahan iklim (Harian Jurnal Asia, 2016).

Tujuan dari penelitian ini adalah membuktikan secara ilmiah pengaruh pertemuan dewan komisaris dan komite audit terhadap manajemen laba karena portfolio pada sektor konstruksi dan bangunan ini menjadi saat ini menjadi salah satu pilar penyokong pertumbuhan ekonomi nasional sehingga dapat diminati oleh investor dan calon investor dibandingkan dengan sektor lainnya. 


\section{Literature Review}

2.1 Teori Agensi

Teori agensi didefinisikan sebagai "Agency theory is a branch of game theory that studies the design of contract to motivate a rational agent to act on behalf of a principal when the agent's interest would otherwise conflict with those of the principal '(Scott, 2015, hal. 340). Teori ini merupakan hubungan kontrak antara pemilik perusahaan (prinsipal) dengan manajemen (agen), dimana pemilik perusahaan memberikan wewenang kepada manajemen untuk menjalankan kegiatan operasional perusahaan. Pemilik perusahaan mengharapkan manajemen dapat memanfaatkan sumber daya yang secara optimal untuk mensejahterakan principal dalam jangka pendek maupun jangka panjang (Hery, 2017, hal. 26). Perbedaan kepentingan di atas dapat menimbulkan konflik keagenan.Konflik ini terjadi karena kecenderungan agen perusahaan tidak bertindak sesuai dengan kepentingan prinsipal.Teori lainnya yang digunakan untuk menjelaskan praktik manajemen laba adalah teori akuntansi positif (positive accounting theory). Teori ini dijadikan acuan yang berfungsi untuk menjelaskan bagaimana prosedur akuntansi yang dipilih manajer sehingga dapat melakukan rekayasa penurunan laba dengan tujuan untuk meminimalkan biaya politik yang harus ditanggung perusahaan terkait dengan regulasi pemerintah, subsidi pemerintah, tarif pajak, tuntutan buruh dan lain sebagainya (Watts \& Zimmerman, 1986; Husain \& Surachman, 2017).

Beberapa alternatif perilaku oportunistik manajer dikaitkan dengan manajemen laba merupakan alat manajer untuk mewujudkan kemauan dan keinginan pribadi dan menggunakan laporan keuangan sebagai media untuk memilih metode akuntansi yang tepat. Dewan komisaris dan komite audit yang secara aktif menerapkan prinsip good corporate governance mampu mengurangi penyimpangan atau indikasi adanya praktik manajemen laba yang dilakukan oleh perusahaan.

\subsection{Non-Discreationary Accruals}

Model manajemen laba dengan pendekatan non-discreationary accruals (NDA) dikembangkan oleh Jones pada tahun 1991 dan cukup populer di kalangan penelitipeneliti akuntansi yang menggunakan konsep manajemen laba. Model ini menggunakan 2 (dua) asumsi sebagai dasar pengembangan, yaitu: (a) akrual periode berjalan yaitu perubahan dalam rekening modal kerja, dimana hal tersebut merupakan hasil dari perubahan yang terjadi di lingkungan ekonomi perusahaan yang dihubungkan dengan perubahan penjualan, sehingga seluruh variabel yang digunakan akan dibagi dengan aset atau penjualan periode sebelumnya; dan (b) gross property, plant dan equipment merupakan salah satu komponen utama yang digunakan untuk menghitung total akrual, khususnya untuk biaya depresiasi non discretionary. Rumus perhitungan model Jones adalah sebagai berikut (Sulistyanto, 2014).:

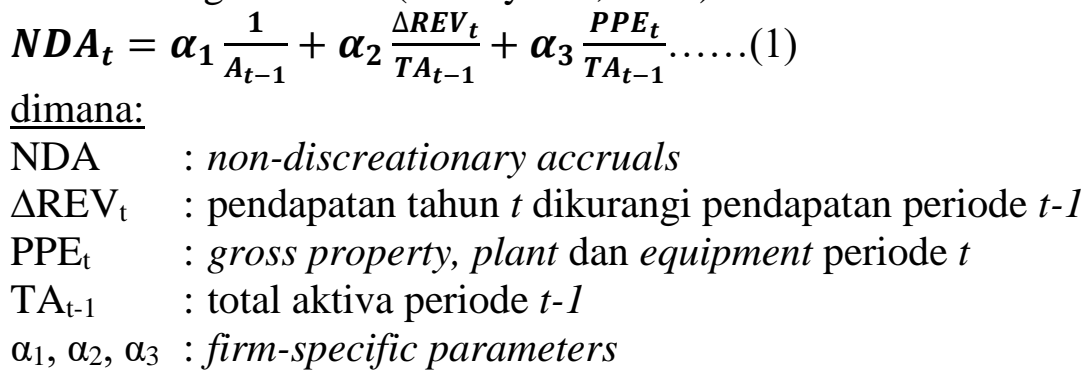




\subsection{Model Penelitian}

Adapun rancangan model penelitian digambarkan sebagai berikut:

\begin{tabular}{|c|c|c|}
\hline Variabel Independen & & Variabel Dependen \\
\hline $\begin{array}{l}\text { Frekuensi Pertemuan: } \\
\text { - Dewan Komisaris (X1) } \\
\text { - Komite Audit (X2) }\end{array}$ & $(-)$ & $\begin{array}{c}\text { Manajemen Laba } \\
\text { (Y) }\end{array}$ \\
\hline
\end{tabular}

Berdasarkan rancangan model penelitian di atas, maka hipotesis yang dirumuskan dalam penelitian ini dinyatakan sebagai berikut:

$\mathrm{H}_{1}$ : Frekuensi pertemuan dewan komisaris berpengaruh negatif terhadap manajemen laba.

H2: Frekuensi pertemuan komite audit berpengaruh negatif terhadap manajemen laba.

\section{Metodologi Penelitian}

Desain penelitian adalah bentuk-bentuk permasalahan dalam penelitian yang dikelompokkan dalam kategori deskriptif, komparatif, dan asosiatif. Penelitian ini merupakanjenis penelitian kausalitas, yaitu tipe penelitian dengan karakteristik masalah berupa hubungan yang bersifat sebab akibat antara variabel independen (variabel yang mempengaruhi) dan dependen (dipengaruhi) (Sugiyono, 2015, hal. 62). Penelitian ini menggunakan pendekatan kuantitatif yang menekankan pada studi empiris untuk membuktikan secara ilmiah pengaruh mekanisme good corporate governance (GCG) dengan pendekatan non-discreationary accruals yang berfokus pada perusahaanperusahaan go-public dengan prosedur statistik. Hasil penelitian diolah secara statistik dengan menggunakan bantuan program SPSS Versi 23.00.

Populasi dalam penelitian ini adalah perusahaan-perusahaan yang terdaftar di Bursa Efek Indonesia (BEI) sub sektor konstruksi dan bangunan selama tahun 2010-2016. Teknik penentuan sampel menggunakan metode purposive sampling yaitu teknik penentuan sampel dengan pertimbangan tertentu (Sugiyono, 2015, hal. 126). Adapun kriteria yang ditetapkan dalam pengambilan sampel pada penelitian ini, yaitu:

1) Perusahaan yang bergerak pada sub sektor konstruksi dan bangunan yang terdaftar di Bursa Efek Indonesia (BEI) tahun 2010-2016.

2) Perusahaan menggunakan data laporan keuangan yang berakhir pada tanggal 31 Desember yang telah diaudit.

3) Perusahaan tidak mengalami kerugian, dan perusahaan memiliki nilai buku ekuitas positif untuk tahun 2010-2016, karena emiten dengan nilai buku ekuitas negatif (bangkrut), dapat mengakibatkan kondisi sampel tidak homogen.

4) Memiliki data lengkap berkaitan dengan variabel-variabel yang digunakan, baik untuk mendeteksi manajemen laba maupun mengetahui mekanisme good corporate governance.

Pengumpulan data dilakukan melalui metode survei dan data-data kuantitatif yang berupa laporan tahunandan laporan keuangan perusahaan tahun 2010-2016. Data sekunder yang dibutuhkan tersebut telah dipublikasikan oleh perusahaan-perusahaan yang terdaftar di Bursa Efek Indonesia (BEI) dan dapat diakses melalui website www.idx.co.id dan website resmi perusahaan. 
Metode analisis data dalam penelitian ini menggunakan teknik analisis regresi berganda. Pengujian ini mensyaratkan asumsi klasik melalui uji normalitas, uji heterokedastisitas, uji multikolinearitas dan uji autokorelasi terlebih dahulu. Adapun model persamaan regresi yang dirumuskan dalam penelitian ini adalah:

$\mathrm{Y}=\alpha+\beta 1 . \mathrm{X} 1+\beta 2 . \mathrm{X} 2+\mathrm{è} \ldots . . .(2)$

dimana:

Y : Manajemen Laba

$\alpha \quad$ : Konstanta

$\beta 1-\beta 2$ : Koefisien regresi masing-masing variabel independen

$\mathrm{X} 1 \quad$ : Frekuensi Pertemuan Dewan Komisaris

X2 : Frekuensi Pertemuan Komite Audit

è : Faktor Penganggu (epsilon)

Untuk mengintepretasikan uji-t terlebih dahulu menentukan nilai $\alpha$ dan degree of freedom (df) dan membandingkan nilai t-hitung dengan t-tabel. Tingkat signifikansi yang digunakan dalam penelitian ini adalah 0,05 dengan kriteria penerimaan hipotesis yang ditetapkan sebagai berikut:

1) Jika nilai t-hitung < t-tabel ( $\mathrm{H}_{0}$ diterima), atau sebaliknya

2) Jika nilai t-hitung $>$ t-tabel (Ha diterima)

\section{Hasil dan Pembahasan}

Penelitian ini menggunakan pengukuran manajemen laba dengan pendekatan nondiscretionary accruals pada model Jones 1991. Adapun nilai rata-rata piutang akrual pada 5 (lima) perusahaan sub sektor konstruksi bangunan yang listing di Bursa Efek Indonesia (BEI) tahun 2010-2016 adalah sebagai berikut:

Gambar 1.Trend Rata-Rata Nilai Piutang Akrual Tahun 2010 - 2016

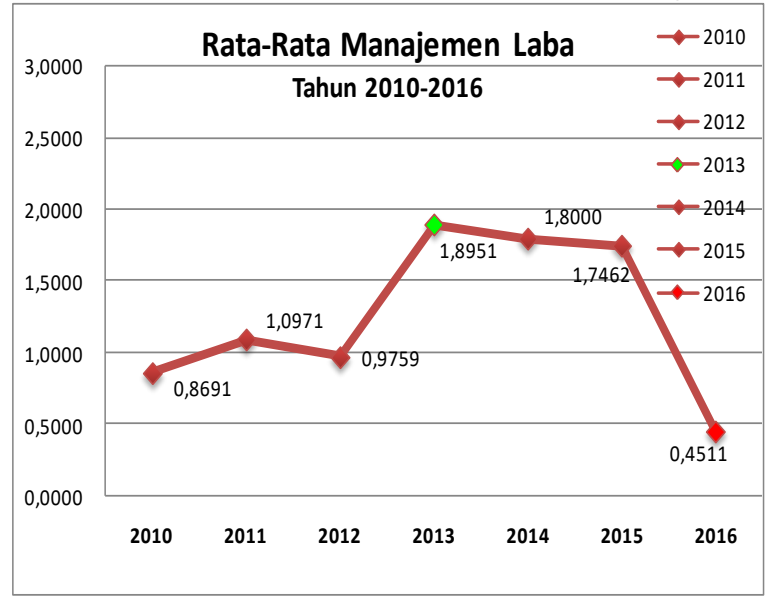

Sumber: Data Diolah (2017)

Indeks nilai rata-rata piutang akrual pada Gambar 1 kategori perusahaan yang terdaftar di BEI sub sektor konstruksi dan bangunan selama tahun 2010-2016 menggunakan pendekatan non-discreationary accruals cukup berfluktuasi. Kenaikan piutang akrual tertinggi berada di tahun 2012-2013 sebesar 0,9192 sedangkan penurunan piutang akrual terjadi pada tahun 2015-2016 sebesar 1,2951. Oleh karenanya indeks tersebut tidak 
berada pada interval residual yang dipersyaratkan pada nilai indeks - $-0,075$ sampai dengan 0,075 (Roychowdurry, 2006). Dengan demikian, trend indeks pada perusahaanperusahaan yang diteliti terindikasi adanya praktik manajemen laba.

Variabel pertemuan dewan komisaris (X1) dan pertemuan komite audit (X2) dan memiliki nilai rata-rata masing-masing sebesar 10,57 kali dan 11,69 kali, hal ini berarti dewan komisaris dan komite audit cukup sering mengadakan pertemuan guna membahas rencana usaha, melaksanakan koordinasi dengan dewan direksi, sekretaris perusahaan dan komite-komite lainnya dalam merumuskan kebijakan-kebijakan perusahaan, khususnya terkait dengan manajemen laba. Adapun nilai standar deviasi diketahui sebesar masing-masing sebesar 5,095 dan 6,097, hal ini dapat dipahami bahwa variasi data pada sampel perusahaan yang diteliti juga relatif besar (nilai mean dibandingkan dengan nilai standar deviasi lebih besar dari 30\%).

Tabel 1. Statistik Deskriptif

\begin{tabular}{llll}
\hline & X1 & X2 & Y \\
\hline Minimum & 4 & 4 & $-0,3225$ \\
Maximum & 20 & 28 & 0,9352 \\
Mean & 10,57 & 11,69 & 0,252420 \\
Std. & 5,095 & 6,057 & 0,239301 \\
Deviation & & & \\
$\mathbf{N}$ & $\mathbf{3 5}$ & \\
Sumber: Data diolah (2017)
\end{tabular}

Variabel manajemen laba (Y) memiliki distribusi nilai minimum dan maksimum masingmasing sebesar $-0,3225$ dan 0,9352. Adapun nilai rata-rata manajemen laba pada perusahaan yang diteliti selama tahun 2012-2016 adalah sebesar 0,252420 dengan standar deviasi sebesar 0,2393011, hal ini dapat dipahami bahwa variasi data pada sampel perusahaan yang diteliti juga relatif besar (nilai mean dibandingkan dengan nilai standar deviasi lebih besar dari $30 \%$ ).

Uji asumsi klasik pertama yaitu normalitas data yang menggunakan pengujian statistik non-parametrik One-Sample Kolmogorov-Smirnov (K/S). Adapun kriteria penerimaan hipotesis ditetapkan sebagai berikut:

1) Jika nilai probabilitas $>0,05$ maka $\mathrm{H}_{0}$ diterima $\rightarrow$ data berdistribusi normal; atau sebaliknya

2) Jika nilai probabilitas $<0,05$ maka $\mathrm{H}_{0}$ ditolak $\rightarrow$ data berdistribusi tidak normal.

Tabel 2. Hasil Uji Normalitas

\begin{tabular}{lc}
\hline & $\begin{array}{l}\text { Unstandardized } \\
\text { Residual }\end{array}$ \\
\hline Kolmogorov-Smirnov Z & 0,074 \\
Asymp. Sig. (2-tailed) & 0,200 \\
\hline $\mathbf{N}$ & $\mathbf{3 5}$ \\
\hline Sumber: Data diolah (2017) &
\end{tabular}


Hasil uji normalitas di atas menunjukkan bahwanilai Kolmogorov-Smirnov Z adalah 0,074 dengan probabilitas yang lebih besar dari 0,05 yaitu sebesar 0,200 (signifikan) sehingga $\mathrm{H}_{0}$ diterima. Artinya, hasil uji One-Sample Kolmogorov-Smirnov (K/S) telah memenuhi asumsi normalitas data. Uji asumsi klasik kedua yaitu heteroskedastisitas dengan cara melihat scatter diagrams.

Gambar 2. Hasil Uji Heteroskedastisitas

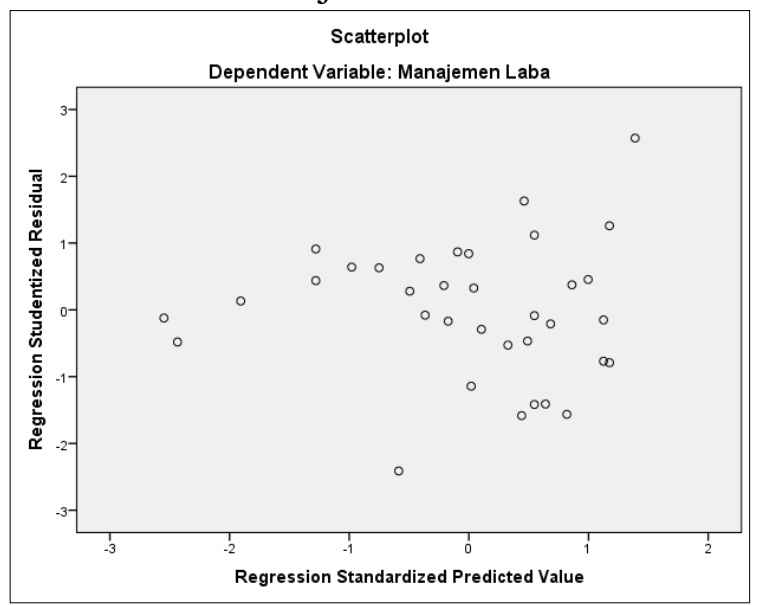

Sumber: Output SPSS 23.00 (2017)

Hasil gambar scatterplot menunjukkan bahwa tidak terdapat pola tertentu yang jelas serta titik-titik menyebar di atas dan di bawah angka 0 pada sumbu $\mathrm{Y}$, maka tidakterjadi heteroskedastisitas. Uji asumsi klasik ketiga yaitu multikolinearitas dengan melihat besaran nilai tolerance dan VIF (varian inflated factor).

Tabel 3. Hasil Uji Multikolinearitas

\begin{tabular}{ccc}
\hline $\begin{array}{l}\text { Variabel } \\
\text { Independen }\end{array}$ & $\begin{array}{l}\text { Nilai } \\
\text { Tolerance }\end{array}$ & $\begin{array}{l}\text { Nilai } \\
\text { VIF }\end{array}$ \\
\hline X1 & 0,792 & 1,262 \\
X2 & 0,792 & 1,262 \\
\hline Sumber: Data diolah $(2017)$ &
\end{tabular}

Hasil uji multikolinearitas di atas menunjukkan bahwanilaitolerance pada masing-masing variabel independen yang lebih besar $(>)$ daripada 0,1 dan nilai VIF lebih kecil $(<)$ daripada 10. Artinya, model regresi terbebas dari multikolinearitas antar variabel independen. Uji asumsi klasik keempat yaitu autokorelasi dengan teknik melihat nilai Durbin-Watson (dw), tingkat signifikansi ditetapkan 0,05 dan k' $=2$.

Tabel 4. Hasil Uji Autokorelasi

\begin{tabular}{lllll}
\hline & $\mathbf{d}_{\mathbf{L}}$ & $\mathbf{d}_{\mathbf{U}}$ & $\mathbf{4 - d} \mathbf{U}$ & $\mathbf{d}_{\mathbf{w}}$ \\
\hline Nilai & 1,3433 & 1,5838 & 2,4162 & 1,001 \\
\hline \multicolumn{2}{l}{ Sumber: Data diolah (2017) }
\end{tabular}


Nilai dw sebesar 1,001 berada lebih kecil dari nilai dL sebesar 1,3433 yang artinya masih terdapat autokorelasi positif antar nilai residual. Model regresi yang baik adalah regresi yang bebas dari autokorelasi. Untuk mengatasi permasalahan autokorelasi dalam penelitian ini, dapat menggunakan teknik pengujian yaitu uji Lagrange Multiplier ( $\mathrm{LM}_{\text {test }}$ ) untuk menghasilkan statistik Breusch-Godfrey. Pengujian ini dilakukan dengan meregresikan variabel penggangu (residual) ut menggunakan autogresive model dengan orde p melalui persamaan berikut ini (Ghozali, 2016):

$|U \mathrm{t}|=\mathrm{p} 1 \mathrm{Ut}-1+\mathrm{p} 1 \mathrm{Ut}-2+\ldots+\mathrm{ppUt}-\mathrm{p}+\varepsilon \mathrm{t}$

Tabel 5. Hasil Uji Autokorelasi (statistik Breusch-Godfrey)

\begin{tabular}{cllll}
\hline & $\mathbf{d}_{\mathbf{L}}$ & $\mathbf{d U}$ & $\mathbf{4 - d U}$ & $\mathbf{d w}_{\mathbf{W}}$ \\
\hline Nilai & 1,3433 & 1,5838 & 2,4162 & 2,053 \\
\hline \multicolumn{2}{l}{ Sumber: Data diolah (2017) }
\end{tabular}

Nilai dw sebesar 2,053 berada di antara nilai du sebesar 1,5838 dan 4-du sebesar 2,4162 sehingga dapat disimpulkan bahwa model regresi tidak menunjukkan terdapat autokorelasi positif atau negatif.

\subsection{Uji Hipotesis}

Hasil pengolahan data statistik menggunakan SPSS 23.00 menghasilkan model persamaan regresi linear berganda pada penelitian ini adalah:

$\mathrm{Y}=0,390+0,004 \mathrm{X} 1+. \mathrm{X} 2-0,015 \mathrm{X} 2+\mathrm{è}$

Tabel 5.Hasil Uji Koefisien Determinasi

\begin{tabular}{cccc}
\hline \multicolumn{1}{c}{$\mathbf{R}$} & R Square & $\begin{array}{l}\text { Std. Error } \\
\text { of Estimate }\end{array}$ \\
\hline Nilai & 0,351 & 0,124 & 0,2309259 \\
Sumber: Data diolah (2017) &
\end{tabular}

Besarnya nilai koefisien korelasi (R) adalah 0,351, dimana berada pada interval 0,200 0,399 artinya hubungan antara variabel independen (frekuensi pertemuan komisaris dan komite audit terhadap variabel dependen (manajemen laba) yang menunjukkan bahwa hubungan yang lemah. Nilai R-Square sebesar 0,124 atau 12,4\% variasi Manajemen Laba (Y) dapat dijelaskan oleh variabel Frekuensi Pertemuan Dewan Komisaris dan Komite Audit. Sedangkan sisanya sebesar 87,6\% dijelaskan oleh variabel lain yang tidak diteliti dalam model regresi ini. Standard error of estimate senilai 0,2309259 merupakan pendugaan kesalahan baku berganda, hal ini berarti model regresi semakin baik dalam tingkat memprediksi Manajemen Laba karena memiliki nilai kurang dari standar deviasi (Y) yaitu sebesar 0,239301.

Tabel 6.Hasil Uji ANOVA

$$
\text { df1 df2 F-Hitung } \begin{array}{cc}
\text { F- } & \text { Probabilitas } \\
\text { Tabel } & \text { Signifikansi } \\
\hline
\end{array}
$$

\begin{tabular}{lllll}
\hline Nilai 2 & 32 & 2,255 & 3,247 & 0,121
\end{tabular}

Sumber: Data diolah (2017) 
Besarnya nilai nilai distribusi $\mathrm{F}$ dengan menggunakan derajat kebebasan $(\mathrm{df} 1)=2$ sebagai numerator dan $(\mathrm{df} 2)=32$ sebagai dominator pada tingkat $\alpha=5 \%$ pada hasil uji ANOVA / Uji-F. Nilai $F_{\text {hitung }}=2,255$ didapatkan lebih kecil dari $F_{\text {tabel }}=3,247$ dengan probabilitas signifikansi yang lebih besar dari 0,05 yaitu 0,121 sehingga Ha ditolak. Artinya, variabel Frekuensi Pertemuan Dewan Komisaris dan Komite Audit secara simultan tidak berpengaruh signifikan terhadap Manajemen Laba.

Tabel 6. Hasil Pengujian

\begin{tabular}{llll}
\hline Hipotesis & $\begin{array}{l}\text { Nilai } \\
\text { t- } \\
\text { hitung }\end{array}$ & $\begin{array}{l}\text { Probabilitas } \\
\text { Signifikansi }\end{array}$ & $\begin{array}{l}\text { Hasil } \\
\text { Pengujian }\end{array}$ \\
\hline $\mathrm{H}_{1}: \mathrm{X} 1 \rightarrow \mathrm{Y}$ & 0,413 & 0,683 & $\begin{array}{l}\text { Tidak } \\
\text { Signifikan }\end{array}$ \\
$\mathrm{H}_{2}: \mathrm{X} 1 \rightarrow \mathrm{Y}$ & $-2,042$ & 0,049 & $\begin{array}{l}\text { Signifikan } \\
\text { negatif }\end{array}$ \\
\hline
\end{tabular}

Sumber: Data diolah (2017)

Variabel frekuensi pertemuan Dewan Komisaris (X1) menghasilkan nilai t-hitung sebesar 0,413 dengan probabilitas sebesar 0,683. Hal ini menunjukkan bahwa frekuensi pertemuan dewan komisaris tidak terbukti berpengaruh signifikan terhadap manajemen laba sehingga menolak $\mathrm{H}_{1}$. Kemudian, variabel frekuensi pertemuan Komite Audit (X2) menghasilkan nilai t-hitung sebesar -2,042 dengan probabilitas sebesar 0,049, hal ini menunjukkan bahwa frekuensi pertemuan komite audit terbukti berpengaruh negatif terhadap manajemen laba sehingga menerima $\mathrm{H}_{2}$.

\subsection{Pembahasan}

Hasil penelitian atas pengujian hipotesis pertama $\left(\mathrm{H}_{1}\right)$ menunjukkan bahwa jumlah pertemuan dewan komisaris berpengaruh negatif dan signifikan terhadap manajemen laba dengan nilai signifikansi sebesar 0,683 ( $p>0,05)$. Hipotesis alternatif pertama yang diajukan yaitu jumlah pertemuan dewan komisaris berpengaruh negatif terhadap manajemen laba sehingga tidak dapat diterima. Temuan penelitian ini mendukung penelitian Prastiti (2013); Marsha dan Ghozali (2017) yang tidak membuktikan pengaruh jumlah pertemuan dewan komisaris terhadap praktik manajemen laba.

Jumlah pertemuan dewan komisaris yang termasuk dalam mekanisme good corporate governance dinilai tidak efektif dan tidak memiliki kekuatan dalam melakukan intervensi kepada pihak manajemen untuk mengurangi praktik manajemen laba. Kondisi ini dapat disebabkan bahwa dewan komisaris juga memiliki kepentingan dalam melakukan praktik manajemen laba. Pertemuan rutin dewan komisaris dalam penelitian ini memiliki nilai rata-rata 10,57 kali atau dikatakan cukup intens (lihat Tabel Statistik Deskriptif). Data di atas menjadi bukti bahwa banyaknya pertemuan dewan komisaris tidak mampu mengevaluasi adanya praktik manajemen laba. Oleh karena itu, banyak atau sedikitnya jumlah pertemuan dewan komisaris tidak mempengaruhi praktik manajemen laba perusahaan.

Hasil penelitian atas pengujian hipotesis kedua $\left(\mathrm{H}_{2}\right)$ menunjukkan bahwa jumlah pertemuan komite audit berpengaruh negatif dan signifikan terhadap manajemen laba 
dengan nilai signifikansi sebesar 0,049 ( $\mathrm{p}<0,05)$. Hipotesis alternatif kedua yang diajukan yaitu jumlah pertemuan komite audit berpengaruh negatif terhadap manajemen laba sehingga dapat diterima. Hasil penelitian ini mendukung penelitian Marsha dan Ghozali (2017) yang membuktikan pengaruh negatif jumlah atau frekuensi pertemuan komite audit terhadap manajemen laba.

Jumlah pertemuan komite audit yang termasuk dalam mekanisme good corporate governance dinilai cukup efektif dan memiliki kekuatan dalam melakukan monitoring kepada pihak manajemen dalam pengambilan keputusan dan mengidentifikasi praktik manajemen laba. Berdasarkan analisis statistik deskriptif menggambarkan bahwa 5 (lima) perusahaan sub sektor konstruksi bangunan yang terdaftar di BEI tahun 2010-2016 memiliki rata-rata jumlah pertemun komite audit yang cukup rutin yaitu 11,69 atau 12 kali. Kondisi ini dapat diyakini bahwa komite audit yang cukup sering mengadakan rapat atau pertemuan menjadi aktivitas rutin yang dilakukan komite audit dalam pelaksanaan tugasnya.Pertemuan secara formal antar anggota komite, dewan komisaris, dewan direksi, maupun auditor eksternal.

Jumlah pertemuan komite audit penelitian ini dinilai cukup efektif dalam mengurangi perilaku oportunistik pihak manajemen sebagai agency dan telah memenuhi persyaratan minimal penyelenggaran rapat secara berkala paling sedikit 1 (satu) kali dalam 3 (tiga) bulan dalam Peraturan OJK Nomor 55/POJK.04/2015 tentang Pembentukan dan Pedoman Pelaksanaan Kerja Komite Audit.

Temuan penelitian ini tidak mendukung penelitian Prastiti (2013) yang menunjukkan bahwa frekuensi pertemuan komite audit tidak berpengaruh signifikan terhadap manajemen laba. Pertemuan formal komite audit merupakan hal penting bagi kesuksesan kinerja komite audit yang membantu dewan komisaris memonitoring aktivitas rutin perusahaan. Dengan demikian, semakin banyak jumlah pertemuan komite audit maka akan berdampak pada menurunnya praktik manajemen laba.

\section{Simpulan}

Berdasarkan hasil pengujian hipotesis pada perusahaan sub sektor konstruksi dan bangunanyang terdaftar di Bursa Efek Indonesia (BEI) tahun 2010-2016 bahwa frekuensi pertemuan Dewan Komisaris tidak berpengaruh signifikan terhadap Manajemen Laba, sedangkan frekuensi pertemuan Komite Audit berpengaruh negatif terhadap manajemen laba.

Hasil penelitian ini dapat menjadi rekomendasi bagi perusahaan untuk lebih hati-hati memilih kebijakan akuntansi dalam melakukan praktik manajemen laba. Selanjutnya, penelitian ini dapat dapat dikembangkan mendatang dengan menambahkan komponen struktur dan mekanisme Good Corporate Governance (GCG) dengan komponen yang lebih lengkap seperti kepemilikan manajerial dan institusional, jumlah dewan komisaris, dewan direksi dan komite audit serta faktor penting lainnya seperti rasio keuangan, ukuran perusahaan dan stock share return. 


\section{Daftar Pustaka}

Algharaballi, E., \& Albuloushi, S. (2008). Evaluating the specification and power of discretionary accruals models in Kuwait. Journal of Derivatives \& Hedge Funds, 14 (3-4), pp. 251-264.

Bareska. (2015). BEI: Laporan Keuangan Inovisi Salah Saji, Suspen Saham Belum Akan Dibuka. Bareksa.com. https://www.bareksa.com/id/text/2015/ 02/25/bei-laporankeuangan-inovisi-salah-saji-suspen-saham-belum-akan-dibuka/ 9562/analysis/

Baskoro, A. (2017). Keberadaan Komite Audit di Indonesia - Serta Peran dan Kontribusi Mereka Dalam Penerapan Enterprise Risk Management (ERM) di Perusahaan. CRMS Indonesia. https://crmsindonesia.org/publications/keberadaan-komite-auditdi-indonesia-serta-peran-dan-kontribusi-mereka-dalam-penerapan-enterprise-riskmanagement-erm-di-perusahaan/

Ghozali, I. (2016). Aplikasi Analisis Multivariate Dengan Program: IBM SPSS 23 (Edisi Ketujuh). Semarang: Badan Penerbit UNDIP.

Harian Jurnal Asia. (2016). Infrastruktur Esensial Berperan Dorong Potensi Properti Indonesia. $\quad$ https://www.jurnalasia.com/bisnis/infrastruktur-esensial-berperandorong-potensi-properti-indonesia/

Hery \& A. Pramono (Eds.). (2017). Kajian Riset Akuntansi Mengulas Berbagai Hasil Penelitian Terkini Dalam Bidang Akuntansi dan Keuangan. Jakarta: PT Grasindo.

Husain, T., \& Surachman, A. E. (2017). Praktik manajemen laba: Studi komparasi pada perusahaan-perusahaan yang melakukan IPO tahun 2012-2016. Jurnal Ilmiah MBiA, $16(1)$, pp. 21-30.

Kompas.com \& J. Primus (Eds.). (2015). Bos Toshiba dilaporkan terlibat skandal penyimpangan akuntansi. https://ekonomi.kompas.com/:https://ekonomi.kompas .com/read/2015/07/21/161317026/.Bos.Toshiba.Dilaporkan.Terlibat.Skandal.Penyi mpangan.Akuntansi.

Marsha, F., \& Ghozali, I. (2017). Pengaruh ukuran komite audit, audit eksternal, jumlah rapat komite audit, jumlah rapat dewan komisaris dan kepemilikan intitusinal terhadap manajemen laba. Diponegoro Journal of Economics, 6(2), 1-12.

OJK. (2015). Salinan Peraturan Otoritas Jasa Keuangan Nomor 55/POJK.04/2015 tentang Pembentukan dan Pedoman Pelaksanaan Kerja Komite Audit. Jakarta.

Prastiti, A., \& Meiranto, W. (2013). Pengaruh karakteristik dewan komisaris dan komite audit terhadap manajemen laba. Diponegoro Journal of Accounting, 2(4), pp.1-12.

Roychowdurry, S. (2006). Earnings Management through Real Activities Manipulation. In R. Watts (Ed.), Journal of Accounting and Economics, 42, 335-370.

Scott, W. R. (2015). Financial Accounting Theory ( $7^{\text {th }}$ ed.). New Jersey: Prentice-Hall International, Inc.

Stubben, S.R. (2010). Discretionary revenues as a measure of earnings management. In M. Trombley (Ed.). The Accounting Review, 85(2), pp.695-717.

Suciningtias, K. (2015). Praktik Earnings management pada perusahaan yang melakukan initial public offering di Bursa Efek Indonesia 2000-2010. Calyptra: Jurnal Ilmiah Mahasiswa Universitas Surabaya, 4(1), 1-15.

Sugiyono. (2015). Metode Penelitian Kombinasi (Mixed Methods). (M. Sutopo, Penyunt.). Cetakan ke-5. Bandung: CV. Alfabeta.

Sulistyanto, H. S. (2014). Manajemen Laba: Teori dan Model Empiris. (M.A. Listyandari, Penyunt.). (Edisi Kedua). Jakarta: Grasindo. 
Watts, R. L., \& Zimmerman, J. L. (1986). Positive Accounting Theory. New Jersey: Englewood Cliffs, Prentice Hall, Inc.

Yasa, G. W., \& Novialy, Y. (2012). Indikasi manajemen laba oleh chief executive officer (ceo) baru pada perusahaan-perusahaan yang terdaftar di Pasar Modal Indonesia. Jurnal Ilmiah Akuntansi dan Bisnis, 7(1), 1-24.

\section{Copyright Disclaimer}

Copyright for this article is retained by the author(s), with first publication rights granted to the journal. 